\title{
A Case Study of Salmonellosis Associated with Consumption of Fresh-market Tomatoes and the Development of a Hazard Analysis Critical Control Points (HACCP) Program
}

\author{
James W. Rushing ${ }^{1}$ \\ Clemson University, Coastal Research and Education Center, 2865 Savannah Highway, Charleston, SC 29414
}

In most developed countries, Salmonella is the main pathogen associated with documented illnesses caused by foodborne microbes (Bean and Griffin, 1990; Buzby et al., 1996). The annual cost of salmonellosis outbreaks in medical fees and time lost from work in the United States was estimated at $\approx \$ 1$ billion in 1989 (Roberts and van Ravenswaay, 1989). By 1996, this estimate had soared to $\$ 3.5$ billion, but the data are subject to interpretation because of: a) the difficulty in estimating medical costs for ill persons; b) the impossible task of determining lost work productivity in unreported cases of illness; and c) the tenuous nature of placing a value on the loss of life (Buzby et al., 1996). There are no reliable estimates of annual losses to businesses.

Salmonellosis was traditionally linked to the consumption of meat

Received for publication 7 Feb 2000. Accepted for publication 8 June 2000. South Carolina Agricultural Experiment Station Technical Contribution No. 4459. The cost of publishing this paper was defrayed in part by the payment of page charges. Under postal regulations, this paper therefore must be hereby marked advertisement solely to indicate this fact.

${ }^{1}$ Associate Professor. E-mail address: jrshng@ clemson.edu and meat products, but in recent years the consumption of raw fruits and vegetables has been implicated in several outbreaks (Beuchat and Ryu, 1997; Brackett, 1998; Buzby, 1995; Hedburg et al., 1994). While the percentage of cases linked to produce is low compared with other foods, there are sufficient incidents to warrant concern. Not only have the food groups changed, but the typical scenario of an outbreak has changed as well. The classic "potato salad at the picnic," where a few people become ill from a poorly handled dish at a single gathering, has given way to a scenario involving low-level contamination of massproduced, widely distributed products that tend to produce sporadic illness across state and national borders (Stephenson, 1997). The case study presented here for tomatoes (Lycopersicon esculentum Mill.) could be typical of virtually any fresh produce item.

\section{THE CRISES}

In 1990, 174 cases of illness associated with Salmonella javiana infection were identified by the U.S. Centers for Disease Control (CDC). An investigation was initiated in Minnesota, the state with the 
largest number of cases, that included the first 35 outbreak-associated culture-confirmed case-patients and 35 neighborhood controls. Only tomato consumption was linked with illness. Case-patients were more likely to have eaten tomatoes from retailers whose regional distributors obtained their tomatoes in part from one shipper in South Carolina. However, Salmonella was not isolated from samples that were obtained from that shipper; the temporal and geographic distribution of tomatoes from the shipper was the only epidemiological link identified for the outbreak (Wood et al., 1991).

In July 1993, the Illinois Dept. of Health noticed an unusual increase in the number of isolates of Salmonella serotype Montevideo in fecal samples. The laboratory had identified 41 isolates compared with a usual monthly average of three to five. In the subsequent investigation by CDC, food exposures of 59 case-patients infected with the outbreak-associated strain, as determined by pulsed-field gel electrophoresis, were compared with 59 age- and sex-matched controls. Consumption of lettuce (Lactuca sativa L.) and tomatoes in restaurants was associated with all cases of infection, but no single restaurant or restaurant chain was implicated. Consumption of lettuce procured as intact heads, but not shredded, was a common factor, but no common sources of lettuce were identified. Consumption of tomatoes from one distributor was associated with Salmonella infection, and these tomatoes were linked to one packer in South Carolina, leading CDC to suggest that tomatoes were the likely source of the illness and that the lettuce had been cross-contaminated during preparation for consumption (Angulo, 1993; Angulo et al., 1994).

Public health authorities in Minnesota and Wisconsin also noted 38 cases of Salmonella montevideo infections during July and Aug. 1993. The ensuing case-controlled study included 17 cases, 13 of which were linked to consumption of tomatoes that originated from the same packinghouse implicated in the Illinois study. Lettuce was not linked to illness. Note that environmental samples obtained from the tomato packinghouse in Sept. 1993, and a physical examination of the facility, failed to identify a source of Salmonella contamination (McFarland et al., 1994).

Compared with other outbreaks of foodborne illness, a relatively small amount of media coverage was associated with the salmonellosis outbreaks (Fairchild, 1990a, 1990b). No deaths occurred, all of the victims recovered fully, and legal proceedings were not initiated. By the time the epidemiological link was established, practically all of the tomatoes from the source had been consumed and Salmonella could not be isolated from the available fruit or from the packing facility. There is no market information indicating that the tomato industry suffered financial losses as a result of the outbreaks; however, there clearly was a need to prevent further incidents of this nature to avoid damage to the industry.

\section{THE LOCAL INDUSTRY RESPONSE}

Following the 1993 outbreak, an epidemiologist from CDC met formally with grower and packer members of the South Carolina Tomato Association (SCTA) and university personnel to brief them on the epidemiologists' findings and assist with the development of a plan to avoid future outbreaks. After an emotional discussion, the SCTA membership elected to provide funding to initiate studies on the problem.

In previous work, Salmonella was isolated from fresh-market tomatoes (Tauxe, 1991), and when placed on cut tomatoes, it multiplied (Asplund and Nurmi, 1991). The next logical step was to determine if the Salmonella strains responsible for the described outbreaks of illness could survive in and on tomatoes that were subjected to the practices utilized by commercial handlers of freshmarket tomatoes.

\section{SURVIVAL OF SALMONELLA IN AND ON TOMATOES}

Zhuang et al. (1995) soon reported that S. montevideo inoculated on the surface of mature-green tomatoes or on chopped ripe tomatoes could grow, and that its growth was temperature-dependent within the range of 10 to $30{ }^{\circ} \mathrm{C}$, conditions that commonly occur in normal postharvest handling systems. The stem scar of the tomato provides a point of entry for Salmonella, and penetration was facilitated by a temperature differential between the fruit and the dip suspension; i.e., more penetration occurred when warm fruit were placed in a cool medium (Zhuang et al., 1995) This phenomenon had been studied previously with tomatoes using decay-causing microorganisms (Bartz and Showalter, 1981), research that is the basis for current recommendations that dump tank water from tomato packinghouses be heated to $\approx 5^{\circ} \mathrm{C}$ warmer than the pulp temperature of the fruit to help avoid any infiltration of contaminated water into the tomato (Showalter, 1993).

Chlorine in the dip suspension inhibited the proliferation of $S$. montevideo on the fruit surface and in the core tissue of mature-green tomatoes (Zhuang et al., 1995), emphasizing the need to effectively manage the disinfecting capacity of water in packinghouse dump tanks. Additional work with sanitizing diced cantaloupe (Cucumis melo L. Cantaloupensis group) led investigators to suggest that chlorine is one of the best broad-spectrum sanitizers available at present. However, the inability of chlorine to kill certain pathogens on alfalfa (Medicago sativa L.) sprouts, plus the fact that its efficacy is limited by the presence of organic matter or initial high populations of microorganisms on produce, indicates that additional research is needed on alternatives to chlorine (Beuchat and Ryu, 1997).

\section{DEVELOPMENT, IMPLEMENTATION, AND VERIFICATION OF A HACCP PROGRAM}

Results of the basic work with Salmonella and tomatoes clearly demonstrated that the industry needed some type of formal protocol for preventing, as much as possible, microbial contamination during postharvest handling of the tomatoes. Broad implementation of HACCP programs in all types of food handling systems had been proposed by the U.S. Food and Drug Administration as the most appropriate method of preventing illness (Taylor, 1994), so we began the task of developing a HACCP for fresh-market tomatoes.

An evaluation of the field production system for fresh-market tomatoes did not reveal a critical point where microbial contamination would be likely to occur. Soil contact with fruit is minimized during production by the use of stakes and ties to hold the vines off the ground, and of plastic mulch. Fertilizer is applied through drip irrigation tubes under the mulch and no organic manures are utilized (Cook et al., 1985). These production practices are fairly common for fresh-market tomatoes throughout the United States and Mexico.

In the harvesting and handling system, three potential control points were identified. The first was cleaning and continuous assurance of cleanliness of the harvest containers and the wooden bins and gondolas used to transport fruit from the field to the packinghouse. All of these containers are stored for most of the year so it was necessary to ensure that contamination by rodents or birds be removed prior to utilizing them for harvest. Secondly, maintenance of water quality in the packinghouse is of paramount importance and is considered a critical control point. The water supply itself can be a source of contamination, or may serve as a vehicle for carrying contamination from any other source to the fruit (Zawel, 1997). Third, hand-sorting of individual tomatoes on the packingline was identified as a point where any worker with soiled hands could potentially contaminate thousands of fruit. Finally, general sanitation practices throughout the facility were upgraded to meet the standards of good management practices (U.S. Food and Drug Administration, 1996). This included pressure cleaning of equipment, floors, drains, and refrigeration coils in ripening rooms before the start of the packing season. Floors were disinfected at the end of each work day and all leaves and other debris were removed from the packingshed. The HACCP program was implemented in Summer 1994, and monitoring has continued until the present.

To ensure that any gross foreign residue, such as bird droppings or rodent nests, was removed from field containers, each container was pressure-washed in the week preceding harvest with a $10 \%$ sodium hypochlorite solution in hot water. Before filling any bin or gondola with fruit, the harvest manager visually inspected it for cleanliness.

The packinghouse dump tank was equipped with a chlorine gas injection system, which was monitored and controlled by an oxidation-reduction potential (ORP) sensor (Decco, Monrovia, Calif.). 
Such sensors have been utilized to indirectly measure free chlorine in water (Robbs et al., 1995). In this application, the target range of free chlorine concentration was between 100 and $200 \mathrm{mg} \cdot \mathrm{L}^{-1}$ free chlorine. The ORP conditions were continuously recorded electronically and an audible alarm was activated any time the ORP was outside the desired range. The chlorinated water passed through a bed of calcium carbonate to adjust the $\mathrm{pH}$ to approximately 7.0 before being released into the dump tank. Dump tank water temperature was maintained at or near 40 ${ }^{\circ} \mathrm{C}$ with a thermostatically controlled gas heater. To ensure that the automated systems were operating appropriately, water quality parameters (i.e., chlorine content, $\mathrm{pH}$, and temperature) were measured manually at $\approx 2$-h intervals and the measurements recorded.

In the event that water quality parameters were not maintained as described above, appropriate corrective action was taken immediately. For example, liquid sodium hypochlorite could be used to supplement chlorine gas if needed, and $\mathrm{pH}$ could be quickly adjusted manually with citric acid or sodium bicarbonate. During the packing season, there was only one incident of failure to control an established limit. In that case chlorine concentration had fallen below the limit for $\approx 1 \mathrm{~h}$. Tomatoes that were packed during this period were placed in a storeroom separate from all other fruit and were not sold until the results of water and tomato analyses for Salmonella indicated that no contamination was present.

Workers who graded the fruit were issued rubber gloves and given instructions to disinfect their hands and the gloves with soap and water before returning to their work station from breaks or visits to the rest room. The supervisor monitored glove use. No exceptions were made for the requirement that gloves be worn.

Direct testing of water and fruit samples for the presence of Salmonella was conducted. On the first $2 \mathrm{~d}$ of packingline operation in 1994 , the CDC collected $\approx 45$ fruit samples ( 20 tomatoes per sample) from the end of the packingline and $\approx 20$ samples of water from the packinghouse dump tank. All of the samples tested negative for the presence of Salmonella and the CDC discontinued monitoring before the close of the 1994 season.

The packer voluntarily initiated his own monitoring program. Tomato samples (five fruit per sample) were collected at $\approx 2$-h intervals throughout the season in 1994. In 1995 the sampling interval was increased to $4 \mathrm{~h}$. All of the samples were analyzed for the presence of Salmonella in a private laboratory. In 1994 and 1995, 158 and 77 samples of tomatoes, respectively, were negative for the presence of Salmonella (Rushing et al., 1996) The packer has continued to conduct the monitoring program voluntarily.

\section{A LONG-TERM APPROACH TO FOOD SAFETY}

Prevention and preparedness are the themes of much of the current literature on coping with food safety issues. Formal guidelines from industry (Zagory and Hurst, 1996; Zawel, 1997) and the federal government (U.S. Food and Drug Administration, 1998) stress the need for proactive measures to reduce the potential for outbreaks of illness associated with the consumption of produce. These guidelines reemphasize much of the information previously published as good management practices for handling foods (U.S. Food and Drug Administration, 1996).

Although industry and government have been actively developing guidelines, addressing certain issues at a more local level is still important. In South Carolina, an Interagency Food Safety Advisory Committee was formed in 1996 for the specific purpose of preparing for food safety crises. The Committee includes an interdisciplinary group of professionals from: Clemson Univ.; the Medical Univ. of South Carolina; the state Dept. of Health and Environmental Control; several divisions of the state Dept. of Agriculture, including Consumer Services, Public Relations, and the Regulatory Offices for poultry, meat, seafood, and horticultural commodities; an epidemiologist from the U.S. Centers for Disease Control; and representatives of numerous food industries, including production agriculture, wholesale supermarket distribution, and restaurant chains.

Most of the Committee members have attended workshops on crisis management, and many have had formal training on conducting interviews with the media. All of the members are familiar with
HACCP principles and several are professional teachers who regularly teach the principles for HACCP program development to their respective industry groups. The short-term objective of the Committee was to become prepared to deal with any food safety crisis in a professional and effective manner. The long-term goals have been focused on educational programming. Formal training on crisis management and "meeting the media" has been made available to any interested party.

A test of the Committee's effectiveness came quickly when an outbreak of Cyclospora illness first appeared in Charleston, S.C., but within a short time had affected more than 1000 people in 11 states (Friend, 1996). As soon as the parasite was identified and an epidemiological link to strawberries (Fragaria $\times$ Ananassa Duch.) was established, the Committee developed a formal statement to be utilized for meeting the media, and two spokespersons were assigned to handle media inquiries. The initial statement simply emphasized the fact that no strawberries originating from South Carolina had been implicated in the outbreak. Some additional information was offered about washing produce before consumption and avoiding cross-contamination during preparation of all foods. As the facts of the case emerged, the media statement was updated.

Since Cyclospora illness was practically unheard of previously, the Committee elected to prepare a statement for family physicians in South Carolina that described the unusual symptoms of the illness and normal methods of treatment. This communication was issued by the office of the Agromedicine Program at the Medical Univ. of South Carolina via facsimile and e-mail to physicians throughout the state. Eventually, the illness was linked to raspberries (Rubus sp. hybrid) originating from Guatemala, causing serious losses to that industry, which has since developed its own program to deal with crisis management (Linden, 1998).

Another issue with long-term implications that was recently addressed in the South Carolina court is the compatibility of new liveanimal operations with existing fresh fruit and vegetable operations. In a ruling that may become a landmark decision, the judiciary system of the state ruled that a newly constructed poultry production facility could not be operated within the proximity of an existing tomato packing and ripening operation (State of South Carolina, 1998). A variety of similar cases may be anticipated in the future.

\section{CURRENT RESEARCH}

Methods for disinfection of produce have been reviewed in some detail (Beuchat, 1992). Two general approaches are taken. The first involves direct disinfection using irradiation or ozone, and the second entails rinsing, dipping, or drenching the product with water containing a sanitizer, such as any one of several chlorinating compounds. Research with ultraviolet light to disinfect apple (Malus $\times$ domestica Borkh.) cider has promise (Gooch, 1998) and the technique may prove to be suitable for water sanitation. More research and validation of the method is required.

Use of chlorine to sanitize water has been the most economical and easiest method to manage, but automation of chlorinating systems has been a challenge. Oxidation-reduction potential (ORP) sensors have been evaluated in some detail. In one carefully controlled laboratory study, the relationship between ORP, free chlorine, and disinfecting capacity of the water was clearly established (Robbs et al., 1995). However, large-scale industrial trials have not been as successful in establishing a clear, consistent relationship between ORP and the survival of coliform bacteria in water (Miller, Western Precooling Systems, Fremont, Calif., personal communication). Refinements in this technology will certainly be forthcoming because of its importance to food industries. A disadvantage is that exposure to chlorine can influence the ripening of some fruit (Hong and Gross, 1998), suggesting that other physiological processes might be affected as well. Additionally, the formation of undesirable chlorinated compounds is of much concern for disposal of the water.

A recent disturbing report shows a clear relationship between Salmonella and soft rot of fresh fruits and vegetables caused by Erwinia carotovora subsp. carotovora (Wells and Butterfield, 1997). The incidence of suspected Salmonella on produce affected by soft rot was twice as high as that occurring on healthy produce. Further, the 
concentration of Salmonella was 37 times as high in the wash from soft-rotted samples as in the wash from healthy samples. In samples that were coinoculated with Salmonella and E. carotovora, the multiplication of Salmonella was three to 10 times as rapid in the presence of E. carotovora than its absence.

Techniques for detection and differentiation of unusual Salmonella serotypes have improved remarkably. A new "smart" computer program is already helping to identify foodborne outbreaks caused by strains of Salmonella that otherwise would have gone undetected. The program, called Salmonella Outbreak Detection Algorithm (SODA), can track almost 50,000 clinical isolates of Salmonella that are serotyped by state public health laboratories each year and electronically reported as they occur to CDC computers. The program quickly picks up any unusual changes in the patterns of Salmonella occurrence. An example of one success story was the early detection of an international outbreak of infection caused by Salmonella serotype Stanley, a very rare strain, that was quickly traced to alfalfa sprouts produced from contaminated seeds. By detecting the serotype and tracing it to the source early in the outbreak, disease was prevented (Stephenson, 1997).

\section{CONCLUSION}

Fresh fruit and vegetable handlers have traditionally regulated their own actions with regard to food safety. Neither the industry nor public agencies want more formal regulation (Rushing and Brooks, 1997), but as epidemiological techniques continue to improve, more outbreaks of foodborne illness probably will be linked to the consumption of fresh produce. Imported produce is often considered, perhaps unfairly, to be less safe than that which is domestically produced (Rushing, 1995). Clearly, any new regulation must be enforced equitably for all foods. Industries that take a proactive approach in regulating their own food safety practices should enjoy an advantage over competitors who do not. This paper provides an overview of an effective food safety program for tomatoes, involving public agencies and an industry organization, that may be a useful model for other produce industries.

\section{Literature Cited}

Angulo, F.J. 1993. Multistate outbreak of Salmonella serotype Montevideo infections: EPI-AID Trip Rpt., 21 Oct. 1993. Centers for Disease Control and Prevention, Atlanta, Ga.

Angulo, F.J., A. Schuchat, and L. Helsel. 1994. Multistate outbreak of Salmonella montevideo infections associated with consumption of tomatoes, Illinois, p. 20 (abstract). In: CDC Epidemic Intelligence Serv. 43rd Annu. Conf., 18-22 Apr. 1994. Centers for Disease Control and Prevention, Atlanta, Ga.

Asplund, K. and E. Nurmi. 1991. The growth of salmonellae in tomatoes. Intl. J. Food Microbiol. 13:177-182.

Bartz, J.A. and R.K. Showalter. 1981. Infiltration of tomatoes by aqueous bacterial suspensions. Phytopathology 71:515-518.

Bean, N.H. and P.M. Griffin. 1990. Foodborne disease outbreaks in the United States, 1973-1987: Pathogens, vehicles, and trends. J. Food Protection 53:810-817.

Beuchat, L.R. 1992. Surface disinfestation of raw produce. Dairy Food Environ. Sanit. 12:6-9.

Beuchat, L.R. and J.H. Ryu. 1997. Produce handling and processing practices. Emerging Infectious Dis. 3:459-465.

Brackett, R. 1998. Incidence, contributing factors, and control of bacterial pathogens in produce. Proc. $23^{\text {rd }}$ Beltsville Symp. on Fresh Fruits and Vegetables: Quality and Food Safety. 3-6 May 1998. Beltsville, Md. (in press).

Buzby, J.C. 1995. Data on foodborne disease cases, severity, and costs, p. 317. In: T. Roberts, H. Jansen, and L. Unnevehr (eds.). Tracking foodborne pathogens from farm to table: Data needs to evaluate control options. U.S. Dept. Agr., Econ. Res. Serv. Misc. Pub. 1532.

Buzby, J.C., T. Roberts, C.-T.J. Lin, and J.M. MacDonald. 1996. Bacterial foodborne disease: Medical costs and productivity losses, p. 14-21. In: U.S.
Dept. Agr., Econ. Res. Serv., Agr. Econ. Rpt. 741.

Cook, W.P., C.E. Drye, and R.P. Griffin. 1985. Commercial tomato production in South Carolina. Clemson Univ. Coop. Ext. Circ. 625, Clemson Univ., Clemson, S.C.

Fairchild, C. 1990a. Tomatoes: Salmonella suspect. The Packer, 11 Aug. 97(32):1A, 6A.

Fairchild, C. 1990b. Salmonella outbreak source sought. The Packer, Aug. 18, 97(33):1A, 7A.

Friend, T. 1996. CDC tries to track illness tied to bad berry patch. USA Today, 28-30 June. p. 1A, 5D

Gooch, J. J. 1998. A light of hope. Amer. Fruit Grower, Apr. 118(4):10-12. Meister, Willoughby, Ohio.

Hedburg, C.W., K.L. MacDonald, and M.T. Osterholm. 1994. Changing epidemiology of food-borne disease: A Minnesota perspective. Clin. Infect. Dis. 18:671-682.

Hong, J.H. and K.C. Gross. 1998. Surface sterilization of whole tomato fruit with sodium hypochlorite influences subsequent postharvest behavior of fresh-cut slices. Postharvest Biol. Technol. 13:51-58.

Linden, T. (ed.). 1998. Guatemalan berries: A positive food safety example for the world. Intl. Produce J. 7(S):1-8.

McFarland, J.W., C. Hedburg, J. Besser-Weik, W. Schell, and M. Osterholm. 1994. A multistate outbreak of Salmonella montevideo infections associated with uncooked tomatoes, Wisconsin and Minnesota, p. 21 (abstract) In: CDC Epidemic Intelligence Serv. 43rd Annu. Conf., Centers for Disease Control and Prevention, Atlanta, Ga.

Robbs, P.G., J.A. Bartz, J.K. Brecht, and S.A. Sargent. 1995. Oxidationreduction potential of chlorine solutions and their toxicity to Erwinia carotovora subsp. carotovora and Geotrichum candidum. Plant Dis. 79:158 162.

Roberts, T. and E. van Ravenswaay. 1989. The economics of safeguarding the U.S. food supply. U.S. Dept. Agr., Econ. Res. Serv., Agr. Info. Bul. 566.

Rushing, J.W. 1995. Food safety in the United States and abroad: An agriculturist's perspective. J. Agromedicine 2:57-69.

Rushing, J.W., F.J. Angulo, and L.R. Beuchat. 1996. Implementation of a HACCP program in a commercial fresh-market tomato packinghouse: A model for the industry. Dairy Food Environ. Sanit. 16:549-553.

Rushing, J.W. and T.W. Brooks. 1997. Implementation of HACCP programs in fresh fruit and vegetable handling systems: Another challenge for regulatory agencies. J. Assoc. Food Drug Officials 61:1-7.

Showalter, R.K. 1993. Postharvest water intake and decay of tomatoes. HortTechnology 3:97-98.

State of South Carolina. 1998. Administrative Law Judge Division. Haley Farms vs. South Carolina Dept. Health Environ. Control. Docket No. $97-$ ALJ-07-198-CC. Columbia, S.C.

Stephenson, J. 1997. New approaches for detecting and curtailing foodborne microbial infections. J. Amer. Med. Assn. 277:1337-1340.

Tauxe, R.V. 1991. Salmonella: A postmodern pathogen. J. Food Protection 54: 563-568.

Taylor, M.R. 1994. FDA's plans for food safety and HACCP-Institutionalizing a philosophy of prevention. Dairy Food Environ. Sanit. 14:256-258.

U.S. Food and Drug Administration. 1996. Current good manufacturing practice in manufacturing, packing, or holding human food. Dept. Health Human Serv. Document 21. CFR Ch. 1, Part 110, p. 206-215.

U.S. Food and Drug Administration. 1998. Guide to minimize food safety hazards for fresh fruit and vegetables. Center for Food Safety and Applied Nutrition, Guidance for Industry Document, Docket No. 97N-0451, Rockville, Md. (http://vm.cfsan.fda.gov/ dms/prodguid.html)

Wells, J.M. and J.E. Butterfield. 1997. Salmonella contamination associated with bacterial soft rot of fresh fruits and vegetables in the marketplace. Plant Dis. 81:867-871.

Wood, R.C., C. Hedburg, and K. White. 1991. A multistate outbreak of Salmonella javiana infections associated with raw tomatoes, p. 69 (abstract). In: CDC Epidemic Intelligence Serv. 40th Annu. Conf., Centers for Disease Control and Prevention, Atlanta, Ga.

Zagory, D. and W.C. Hurst (eds.). 1996. Food safety guidelines for the freshcut produce industry, $3^{\text {rd }}$ ed. Intl. Fresh-Cut Produce Assoc., Alexandria, Va.

Zawel, S. 1997. Industrywide guidance to minimize microbiological food safety risks for produce. United Fresh Fruit and Veg. Assoc., Alexandria, Va.

Zhuang, R.Y., L.R. Beuchat, and F.J. Angulo. 1995. Fate of Salmonella montevideo on and in raw tomatoes as affected by temperature and chlorine. Appl. Environ. Microbiol. 61:2127-2131. 